\title{
SISTEM INFORMASI USAHA DAGANG BERBASIS DESKTOP (STUDI KASUS: TOKO SOBANA II)
}

\author{
Mari Rahmawati \\ Program Studi Sistem Informasi Akuntansi \\ Universitas Bina Sarana Informatika \\ Jl. Kamal Raya No.18, Ringroad Barat, Cengkareng, Jakarta Barat \\ e-mail: mari.mrw@bsi.ac.id
}

\begin{abstract}
Abstrak:
Perkembangan sistem informasi telah banyak digunakan untuk mendukung proses bisnis yang terjadi di usaha dagang. Untuk dapat melaksanakan kegiatan pembelian yang baik, setiap usaha perlu memiliki sistem informasi yang baik dan terkendali dengan alur yang jelas. Pengelolaan data dan informasi yang baik dapat memudahkan pihak manajemen dalam pengambilan keputusan dan langkah kebijaksanaan yang diperlukan demi
\end{abstract}

\section{Pendahuluan}

Perkembangan teknologi informasi dan komputer yang semakin pesat saat ini telah banyak digunakan di segala bidang, terutama untuk mendukung proses bisnis yang terjadi di perusahaan. Dengan didukung oleh Teknologi Informasi dan Komputer, pencatatan transaksi bisnis yang dahulu dilakukan secara manual, yang menggunakan buku dan kertas telah diganti dengan pencatatan menggunakan media komputer (Rahmawati, 2015). Hal tersebut berdampak terhadap kemajuan bisnis dalam bentuk peningkatan efisiensi dan efektivitas dalam pelaksanaan berbagai tugas atau aktifitas harian perusahaan.

Usaha dagang merupakan salah satu proses bisnis penting yang dilakukan, untuk dapat melaksanakan kegiatan pembelian yang baik, setiap usaha perlu memiliki sistem informasi yang baik dan terkendali dengan alur yang jelas. Pengelolaan data dan informasi yang baik sangat diperlukan oleh pihak manajemen untuk dapat memudahkan dalam pengambilan keputusan dan langkah kebijaksanaan yang diperlukan demi kelangsungan hidup usaha tersebut.

Dengan memanfaatkan perkembangan teknologi informasi dan komputer diharapkan dapat mendukung proses penjualan dan pembelian pada Toko Sabana II yang akan memberikan dampak positif yang besar untuk jalannya bisnis yang dibangun, dapat menjalankan segala aktivitas pelayanan terhadap pelanggan dengan data yang akurat, waktu yang cepat dan dapat memberikan pelayanan yang terbaik kepada pelanggan. (Ramanda, Rusman, \& Agustin, 2017)

\section{Metode Penelitian}

kelangsungan hidup usaha tersebut. Perancangan sistem diharapkan menghasilkan program aplikasi usaha dagang mulai dari input data customer, input data barang sampai cetak laporan sehingga aplikasi ini dapat memberikan dampak positif untuk jalannya bisnis yang dibangun, mengurangi fungsi - fungsi yang terduplikasi, dan mengurangi kesalahan yang disebabkan human error.

Kata kunci: Sistem, Informasi, Usaha Dagang

\subsection{Pengertian Sistem Informasi}

Sistem informasi mempunyai peran penting dalam kinerja sebuah organisasi. Sistem informasi memberikan banyak keuntungan, dari tugas yang simple seperti proses transaksi pada level operasional sampai ke tugas yang sulit seperti membuat keputusan penting dan kompetitif pada tingkat strategis organisasi.

(Anggraeni \& Irviani, 2017) dalam bukunya menerangkan bahwa sistem informasi yaitu suatu sistem yang menyediakan informasi untuk manajemen dalam mengambil keputusan dan juga untuk menjalankan operasional perusahaan, dimana sistem tersebut merupakan kombinasi dari orangorang, teknologi informasi dan prosedur-prosedur yang terorganisasi. Fungsi sistem informasi yang dijelaskan oleh (Anggraeni \& Irviani, 2017) yaitu :

a. Untuk meningkatkan aksesibilitas data yang ada secara efektif dan efisien kepada pengguna, tanpa dengan perantara sistem informasi.

b. Memperbaiki produktivitas aplikasi pengembangan dan pemeliharaan sistem.

c. Menjamin tersedianya kualitas dan keterampilan pendukung sistem informasi.

d. Mengidentifikasi kebutuhan mengenai keterampilan pendukung sistem informasi.

e. Mengantisipasi dan memahami akan konsekuensi ekonomi.

f. Menetapkan investasi yang akan diarahkan pada sistem informasi.

g. Mengembangkan proses perencanaan yang efektif.

Sistem informasi dapat digunakan untuk mendapatkan data, mengolah data menjadi informasi dan menyebar informasi hasil pengolahan data yang sebelumnya untuk menunjang kegiatan operasional 
sehari-hari sekaligus menunjang kegiatan pengambilan keputusan yang strategis (Bakhri, 2015).

\subsection{Usaha Dagang}

Aktivitas perusahaan dagang meliputi pembelian barang dagangan dari supplier (pemasok) dan kemudian menjual kembali barang dagangan yang telah dibelinya tersebut kepada konsumen/pelanggan dengan maksud untuk memperoleh keuntungan. Ketika barang dagangan dijual, nilai dari transaksi penjualan ini akan dilaporkan sebagai pendapatan penjualan (sales revenue) dan harga pokok dari barang yang dijual akan diakui sebagai beban yang dinamakan harga pokok penjualan (cost of goals sold). (Hery, 2012)

\subsection{Permodelan Sistem Berbasis Objek (PSBO)}

Dalam (Rosa \& Shalahuddin, 2016), Metodologi berorientasi objek adalah suatu strategi pembangunan perangkat lunak sebagai kumpulan objek yang berisi data dan operasi yang diberlakukan terhadapnya. Metodologi berorientasi objek merupakan suatu cara bagaimana sistem perangkat lunak dibangun melalui pendekatan objek secara sistematis. Object Oriented Programming (OOP) memfokuskan objek dimana sistem nantinya dibangun akan dibagi ke dalam beberapa objek yang ada di dalamya.

\subsection{Proses Bisnis}

Proses bisnis adalah suatu kumpulan aktivitas atau pekerjaan terstruktur yang saling terkait untuk menyelesaikan suatu masalah tertentu atau yang menghasilkan produk atau layanan (demi meraih tujuan tertentu). (Puspitasari, 2015) menerangkan bahwa pengamatan terhadap analisa sistem berjalan dilakukan untuk mengetahui sistem yang saat ini sedang berjalan serta mengenali kebutuhankebutuhan pengguna serta menemukan kendalakendala yang ada pada sistem yang berjalan dan memberikan alternatif pemecahan masalah.

\subsection{Unified Modelling Languange (UML)}

Unified Modelling Languange (UML) yang berarti bahasa permodelan standar. Dalam (Muslihudin \& Oktafianto, 2016), Chonoles mengatakan sebagai bahasa, berarti UML memiliki sintaks dan semantik. Pembuatan model menggunakan konsep UML ada aturan - aturan yang harus diikuti. Bagaimana elemen pada model model UML berhubungan satu dengan yang lainnya harus mengikuti standar yang ada. UML bukan sekedar diagram, tetapi juga menceritakan konteksnya.

(Muslihudin \& Oktafianto, 2016) juga menjelaskan UML diaplikasikan untuk maksud tertentu, biasanya antara lain :

a. Merancang perangkat lunak. b. Sarana komunikasi antara perangkat lunak dan proses bisnis.

c. Menjabarkan sistem secara rinci untuk analisis dan mencari apa yang diperlukan sistem.

d. Mendokumentasi sistem yang ada, proses-proses dan organisasinya.

\subsection{User Interface}

Menurut (Syahputra \& Amin, 2016), "Desain User Interface atau biasa disebut UI adalah faktor yang sangat penting untuk membuat aplikasi. User biasanya lebih suka berinteraksi dengan antarmuka sesederhana mungkin.”.

User Interface berfungsi untuk :

a. Menghubungkan antara pengguna dengan sistem operasi sehingga komputer dapat digunakan.

b. Menampilkan penjelasan sistem dan memberikan panduan pemakain sistem secara menyeluruh step by step sehingga user mengerti apa yang akan dilakukan terhadap suatu system.

c. Kemudahan dalam memakai / menjalankan sistem, interaktif, komunikatif.

Perancangan antarmuka memfokuskan pada tiga area yaitu rancangan antarmuka antara modul-modul perangkat lunak, rancangan antarmuka antara perangkat lunak dengan entitas eksternal dan rancangan antarmuka antara perangkat lunak dengan pengguna perangkat lunak (manusia dengan komputer).

\section{Hasil dan Pembahasan}

\subsection{Tinjauan Perusahaan}

Toko SOBANA II berdiri sekitar tahun 2008 terletak di Jl. Kebagusan Raya, Pasar Minggu Jakarta Selatan, suatu badan wirausaha milik pribadi yang bergerak dibidang penjualan snack/makanan ringan. Berdasarkan kebutuhan serta besarnya minat akan penjualan yang profesional dan kompetitif dengan tidak mengesampingkan kualitas dari produk tersebut. Toko ini masih menggunakan cara manual pada pengecekan stock barang, pembayaran di kasir dan membuat laporan keuangan pe-periode, stock barang juga sangat dijaga untuk kelangsungan toko ini, mereka menggunakan metode First In First Out (FIFO) untuk menjaga kualitas barang-barang. Dengan adanya kebutuhan yang semakin berkembang toko ini akan memperbaiki sistemnya dengan menggunakan sistem informasi agar pekerjaan dapat berjalan efektif dan efisien.

\subsection{Proses Bisnis Sistem berjalan}

a. Pemesanan Barang

Bagian gudang mengecek stock barang untuk mengetahui persedian barang yang ada di gudang. Ketika barang yang ada di gudang sudah menunjukan batas minimal yang artinya bagian gudang harus segera menginformasikan dan membuat surat permintaan pesanan kepada bagian kasir untuk segera melakukan permintaan 
barang, kemudian bagian kasir menginformasikan pesanan kepada supplier.

b. Penerimaan Barang

Supplier akan mengirim barang pesanan kepada toko, kemudian bagian kasir menerima barang yang telah di kirim oleh supplier dan mengecek pesenan barang sesuai dengan surat permintaan pesanan. Kemudian supplier memberikan faktur pembelian kepada kasir untuk dijadikan arsip di toko.

c. Pembayaran

Berdasarkan faktur pembelian dan surat pesanan maka bagian kasir melakukan pembayaran secara tunai dengan jumlah yang tertera pada faktur pembelian, kemudian bagian kasir membuatkan bukti pembayaran kepada supplier.

d. Pembuatan laporan

Bagian kasir membuat laporan pembelian dan laporan keuangan berdasarkan arsip pembelian dan nota bukti pembayaran kepada supplier, kemudian laporan tersebut di serahkan kepada pemilik toko.

\subsection{Permasalahan Pokok}

a. Pengecekan stock barang di bagian gudang yang masih manual.

b. Sistem pembayaran yang masih menggunakan kalkulator untuk menghitung.

c. Penyusunan laporan pembelian masih berpacu pada nota dan faktur pembelian.

\subsection{Pemecahan Masalah}

Dengan menggunakan Sistem Informasi dapat:

a. Memudahkan penginputan data barang dan pengecekan stok barang.

b. Pembuatan laporan dapat terfokus dengan baik dan lebih mudah dalam pencarian laporan harian, bulanan, dan tahunan.

\subsection{Analisa Kebutuhan}

Berdasarkan proses bisnis berjalan maka tahapan berikutnya adalah analisa kebutuhan, berikut ini adalah analisa kebutuhan dari sistem pembelian. Pembelian menginput semua transaksi pembelian dan membuat laporan atas pembelian.

Analisa Kebutuhan user akan sistem dapat diuraikan sebagai berikut :

\section{A.1. Bagian Kasir mengakse login}
a. Menginput nama user
b. Menginput Password
c. Masuk atau Keluar

A.2. Bagian Pembelian mengakses menu utama
a. Mengaskes menu master
b. Mengaskes menu transaksi
c. Mengaskes menu laporan
d. Mengaskes menu keluar

A.3. Bagian Kasir mengaskes menu master
A3.1. Bagian Kasir mengelola data user

a. Dapat menambah data user

b. Dapat menyimpan data user c. Dapat mengubah data user

d. Keluar

A3.2. Bagian Kasir mengelola data perkiran

a. Dapat menyimpan data perkiraan

b. Keluar

A3.3. Bagian Kasir mengelolah data supplier

a. Dapat menambah data supplier

b. Dapat menyimpan data supplier

c. Dapat mengubah data supplier

d. Keluar

A3.4. Bagian Kasir mengelola data barang dagang

a. Dapat menambah data barang dagang

b. Dapat menyimpan data barang dagang

c. Dapat mengubah data barang dagang

d. Keluar

A4. Bagian Kasir mengaskes menu transaksi

A4.1. Bagian Kasir mengelola data purchase order (PO)

a. Dapat menambah data PO

b. Dapat menyimpan data PO

c. Dapat mengubah data PO

d. Keluar

A4.2. Bagian Kasir mengelola penerimaan barang

a. Dapat menambah data penerimaan barang

b. Dapat menyimpan data penerimaan barang

c. Dapat mengubah data penerimaan barang

d. Keluar

A4.3. Bagian Kasir mengelola faktur/bon pembelian

a. Dapat menambah data faktur/bon pembelian

b. Dapat menyimpan data faktur/bon pembelian

c. Dapat mengubah data faktur/bon pembelian

d. Keluar

A4.4. Bagian Kasir mengelola pengeluaran kas

a. Dapat menambah data pengeluaran kas

b. Dapat menyimpan data pengeluaran kas

c. Dapat mengubah data pengeluaran kas

d. Keluar

A4.5. Bagian Kasir mengelola jurnal transaksi

a. Dapat menambah data jurnal transaksi

b. Dapat menyimpan data jurnal transaksi

c. Dapat mengubah data jurnal transaksi

d. Keluar

A5. Bagian Kasir mengaskes menu laporan A5.1. Bagian Kasir dapat megelola from pembelian

a. Mencetak laporan pembelian

b. Keluar

A5.2. Bagian Kasir dapat megelola from pengeluaran kas

a. Mencetak laporan pembelian

b. Keluar 


\subsection{Use case diagram menu utama}

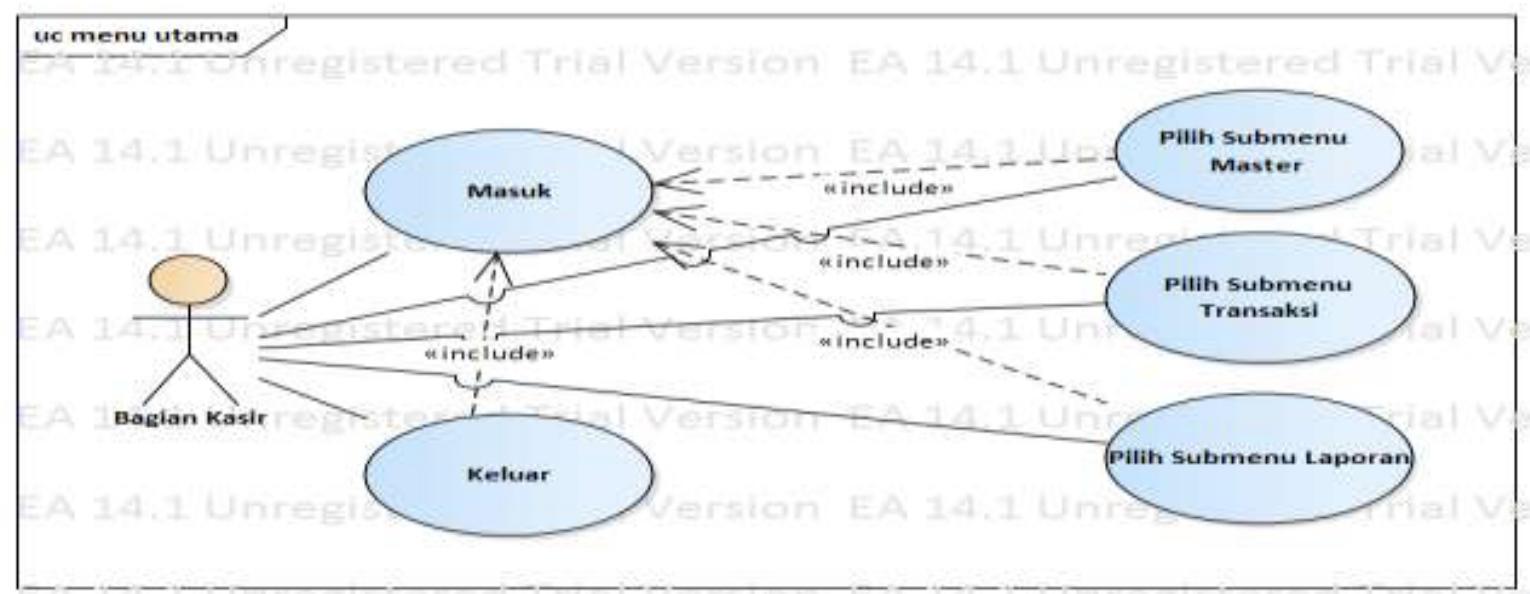

Gambar III.1

Use Case diagram menu utama

Tabel III.1

User Case Description Menu Utama

\begin{tabular}{|c|c|}
\hline \multicolumn{2}{|c|}{ Use Case Description Login } \\
\hline Tujuan & $\begin{array}{l}\text { Bagian pembelian dapat melakukan pengolahan data yang } \\
\text { ada di menu utama }\end{array}$ \\
\hline Deskripsi & $\begin{array}{l}\text { Sistem ini memungkinkan aktor untuk mengelola sistem } \\
\text { pencatatan data pembelian mulai dari input bon pembelian, } \\
\text { pengeluaran kas, hingga laporan }\end{array}$ \\
\hline & Skenario Utama \\
\hline Aktor & Bagian Pembelian \\
\hline Kondisi Awal & Aktor membuka aplikasi pembelian \\
\hline Aksi Aktor & Reaksi Sistem \\
\hline $\begin{array}{l}\text { 1.Aktor memilih menu Master } \\
\text { 2. Aktor memilih menu Transaksi } \\
\text { 3. Aktor memilih menu Laporan } \\
\text { 4.Aktor memilh menu Keluar }\end{array}$ & $\begin{array}{l}\text { 1. Sistem akan menampilkan submenu yaitu data perkiraan, } \\
\text { data supplier, dan data bahan baku } \\
\text { 2.Sistem akan menampilkan submenu yaitu transaksi } \\
\text { purchase order, penerimaan barang, transaksi bon } \\
\text { pembelian dan transaksi pengeluaran kas } \\
\text { 3. Sistem akan menampilkan submenuyaitu laporan } \\
\text { pembelian, laporan pengeluaran kas, dan jurnal umum } \\
\text { 4. Sistem akan keluar dan kembali ke menu awal login }\end{array}$ \\
\hline kondisi Akhir & $\begin{array}{l}\text { Jika perintah sesuai maka sistem akanmenampikan data } \\
\text { sesuai yang diinginkan actor }\end{array}$ \\
\hline
\end{tabular}

\subsection{Activity Diagram Menu Utama}




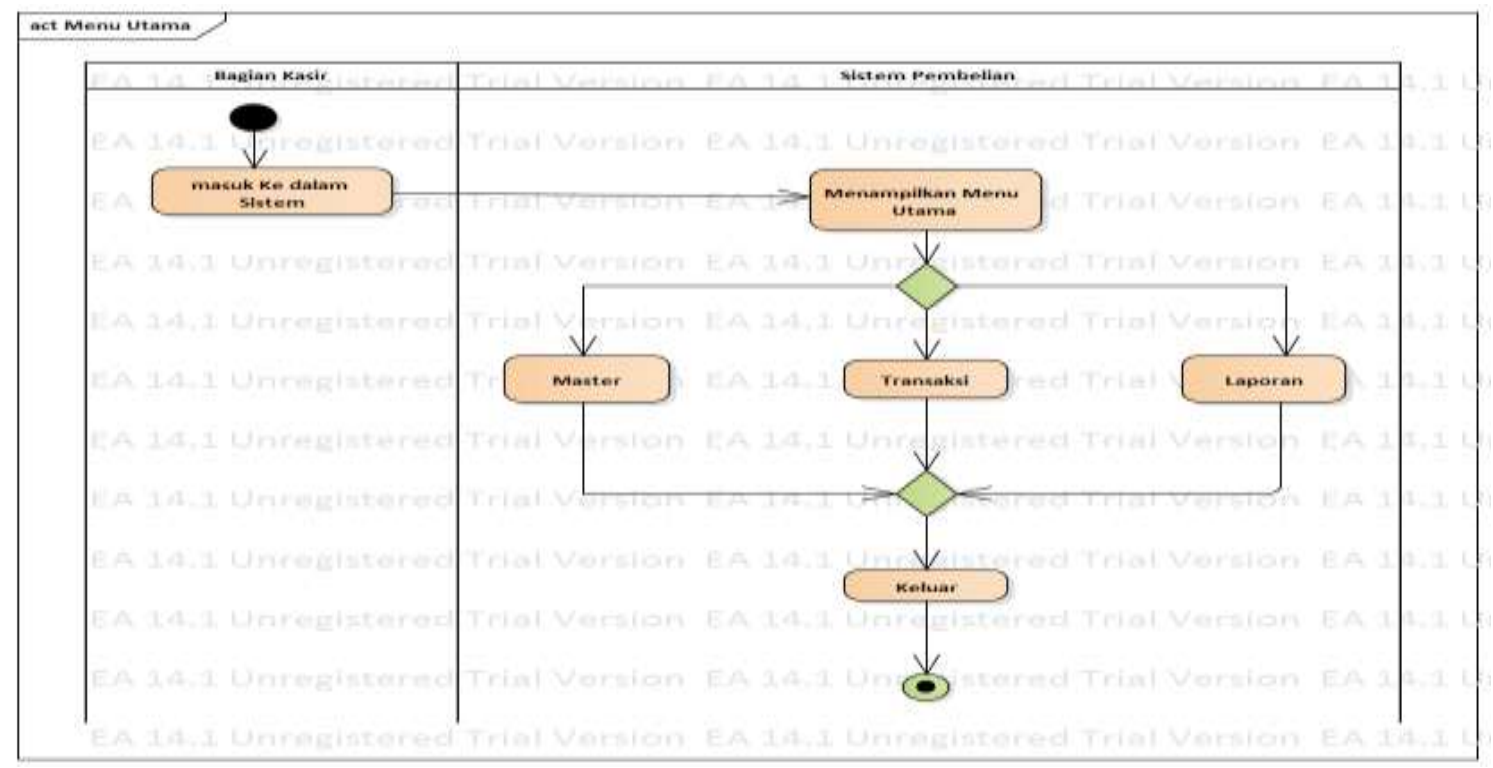

Gambar III.2

Activity Diagram Menu Utama

\subsection{Entity Relatinship Diagram (ERD)}

ERD adalah sebuah alat yang menujukan hubungan antara entitas dalam suatu sistem. berikut adalah penggambaran ERD:

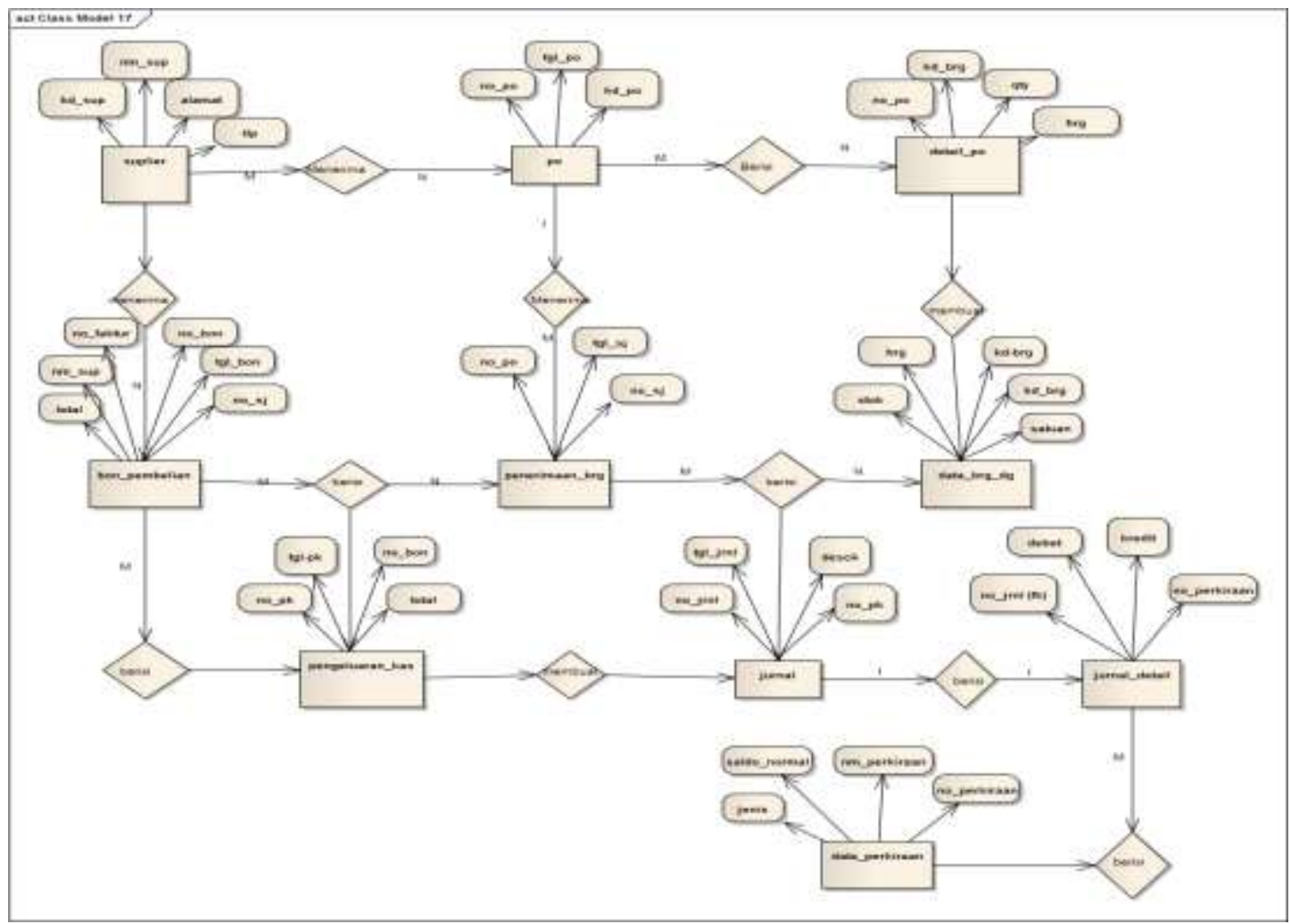

Gambar III.3

Entity Relationship Diagram (ERD)

3.9 Logical Record Structure (LRS) 


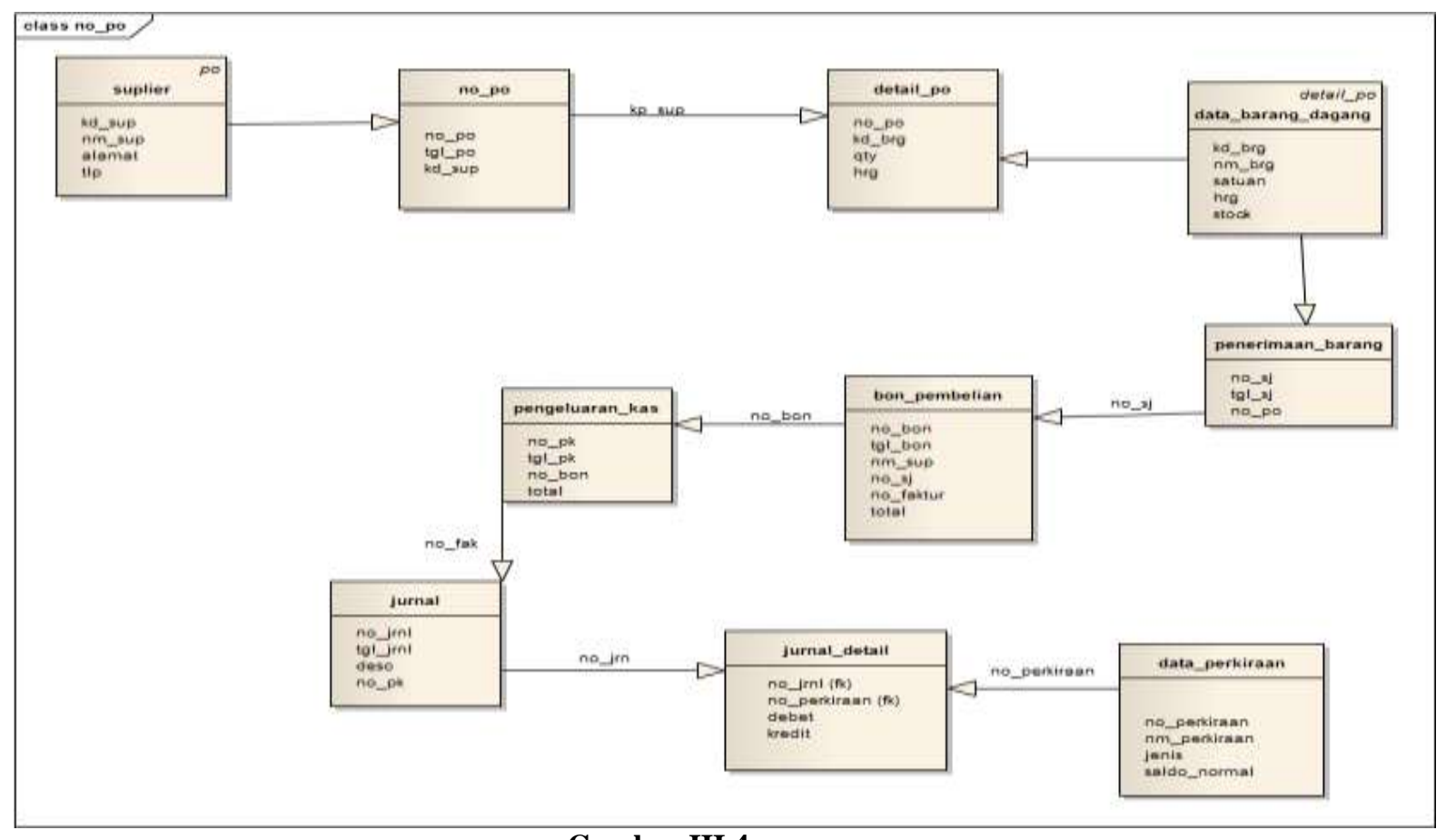

Gambar III.4

Logical Record Structure (LRS)

\subsection{Sequence Diagram}

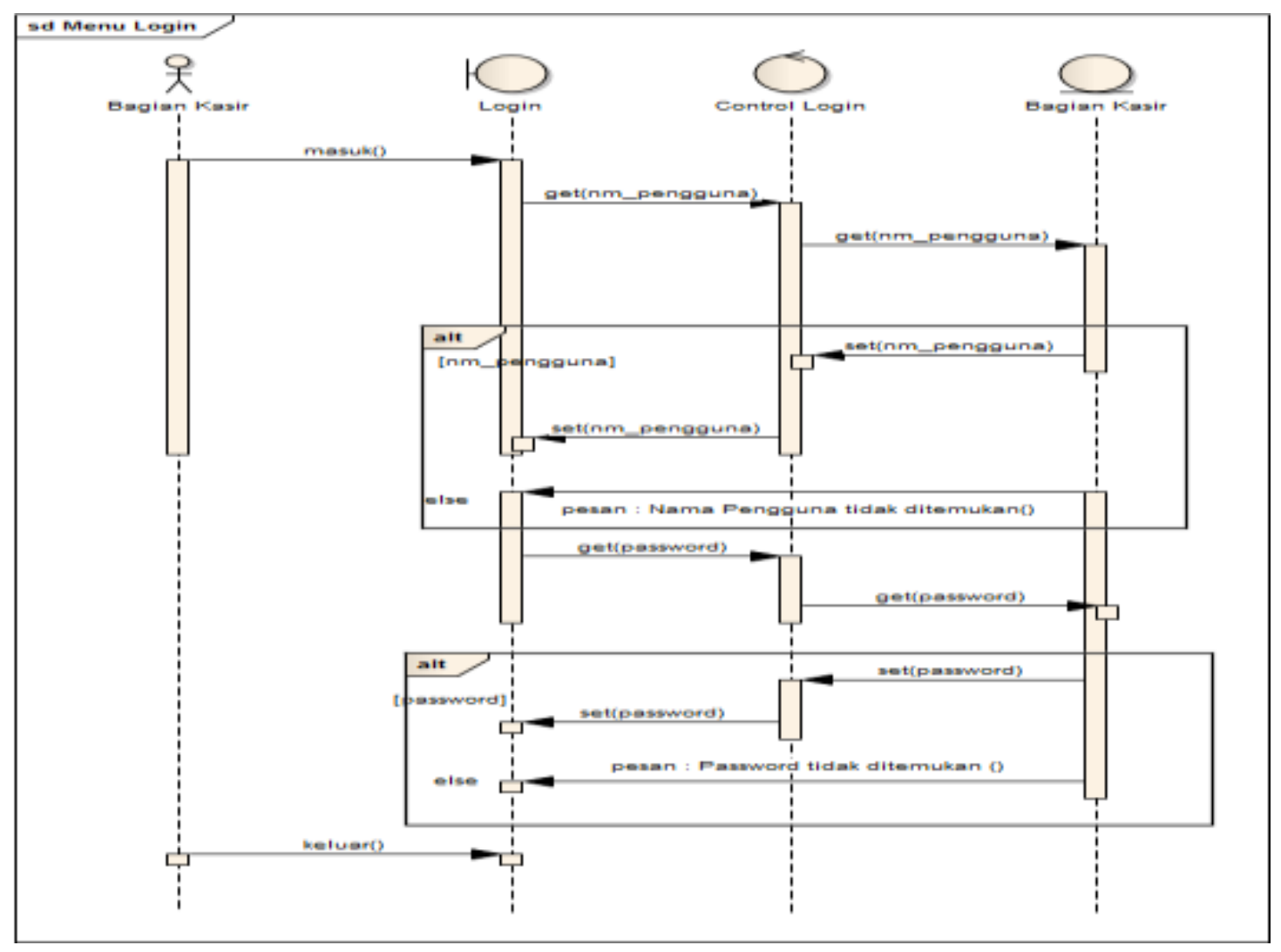

Gambar III.5

Sequnce Diagram Menu Login 


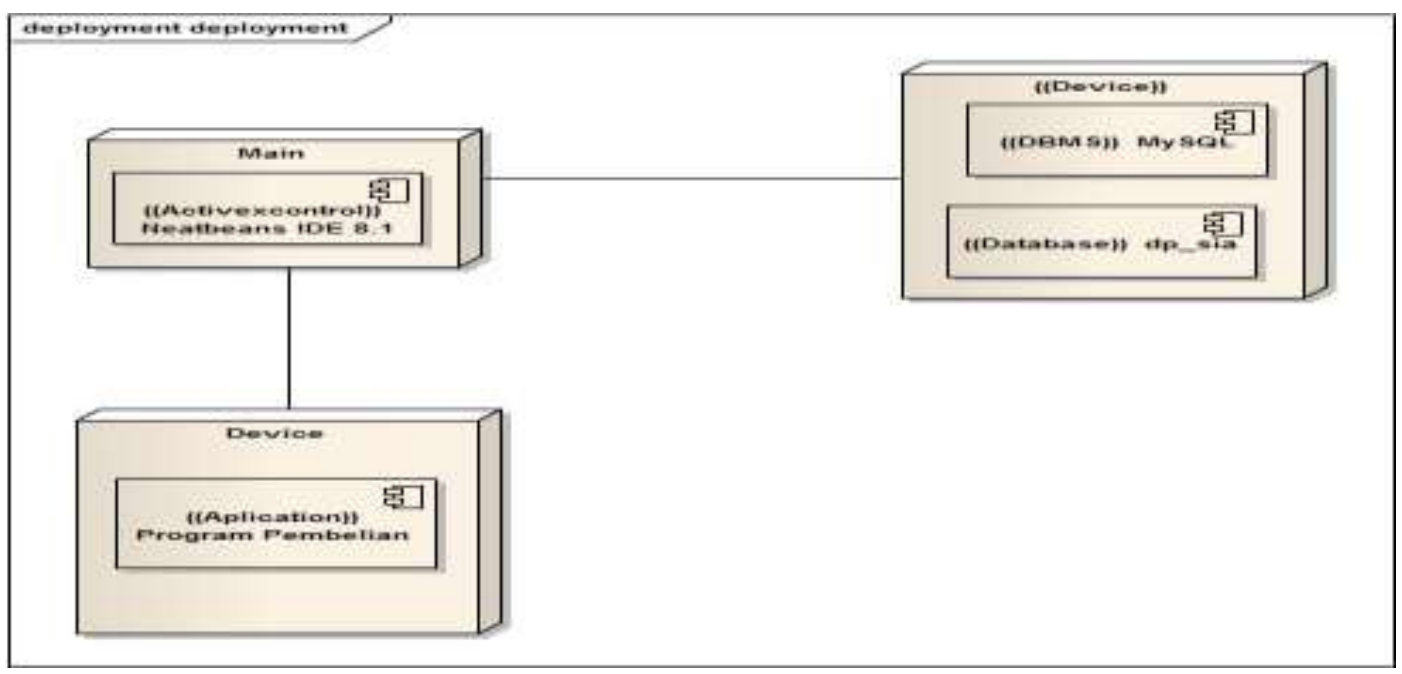

Gambar III.6

3.12 User Interface Menu Master

Deployment Diagram

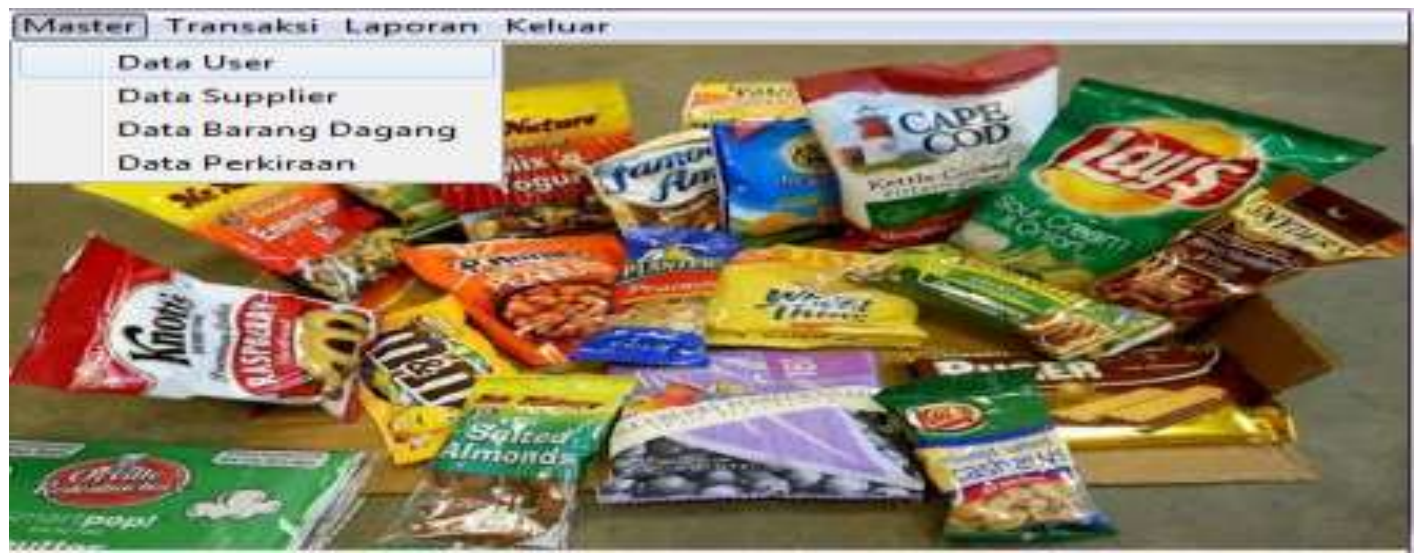

Gambar III.7

Menu Master

3.13 User Interface Form Data Supplier

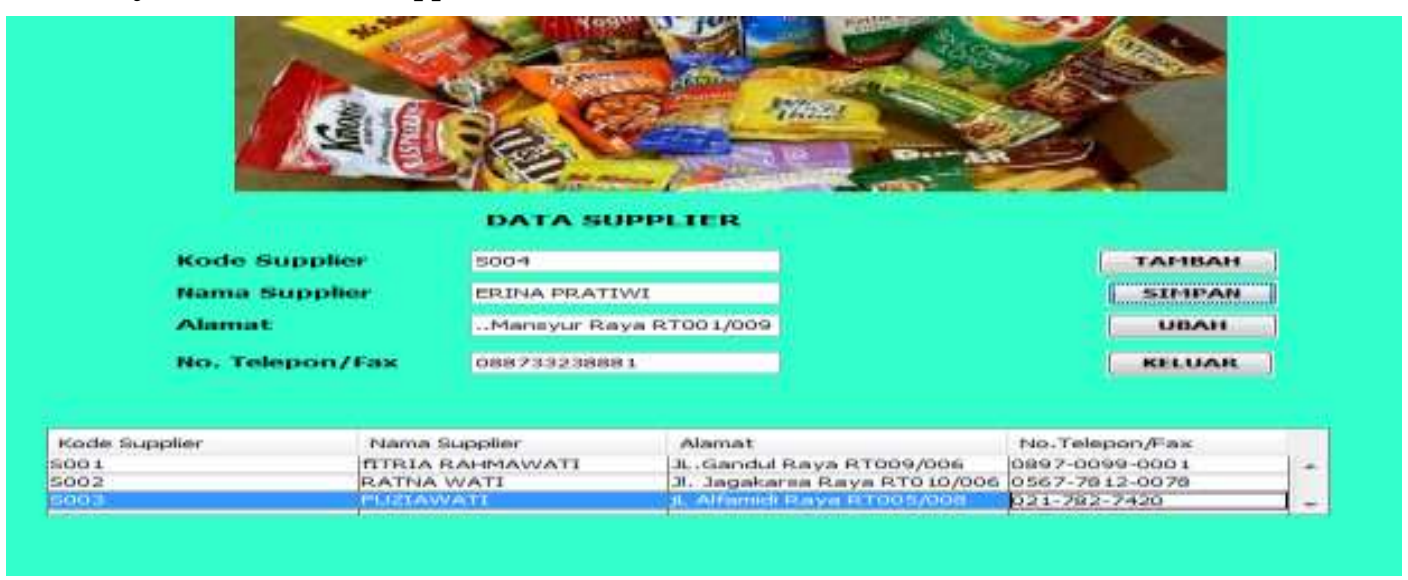

Gambar III.8

User Interface Form Data Supplier 
3.13 User Interface Menu Transaksi

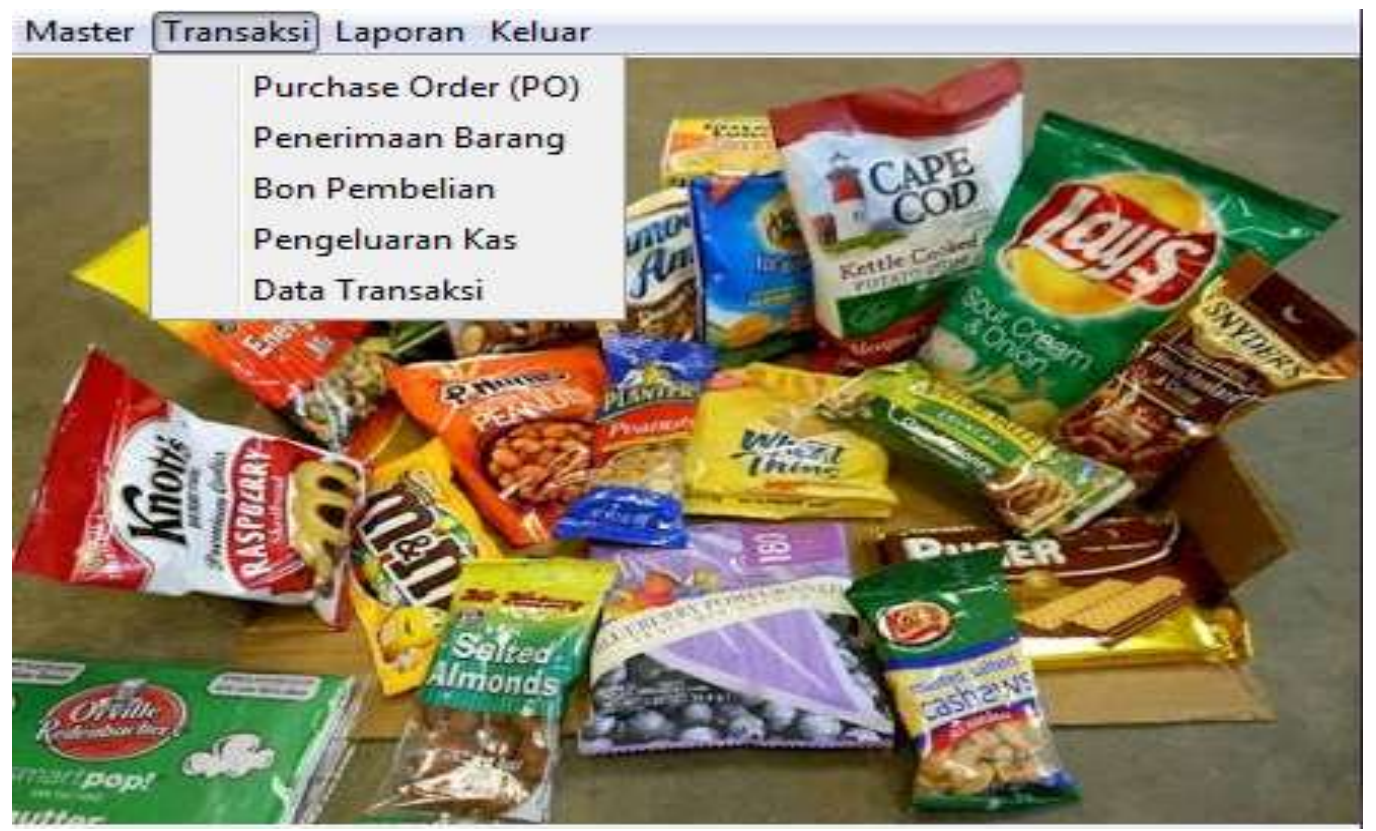

Gambar III.9

Menu Transaksi

\subsection{User Interface Form Purchase Order}

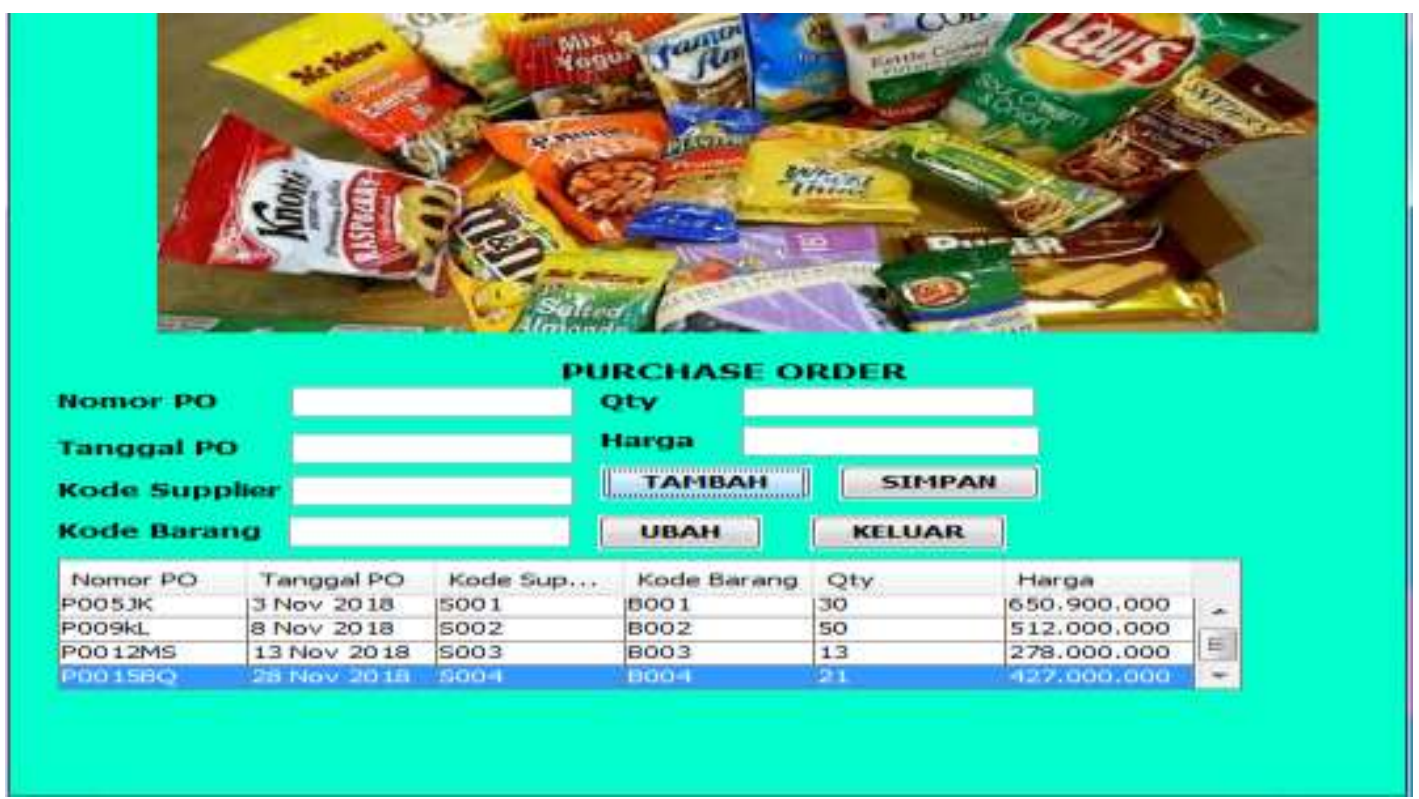

Gambar III.10

User Interface Form Purchase Order 


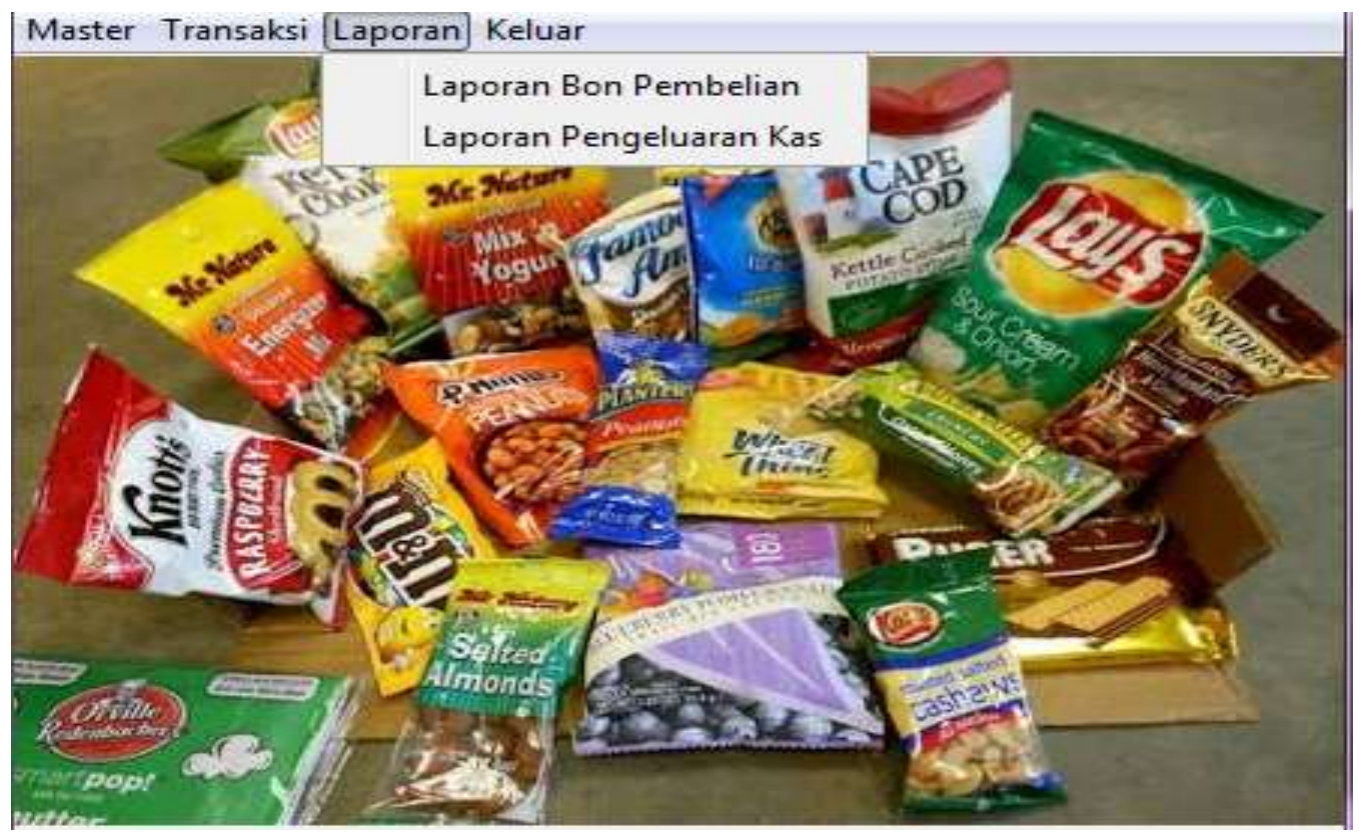

Gambar III.11

User Interface Menu Data Laporan

3.16 UserInterface Laporan Pembelian

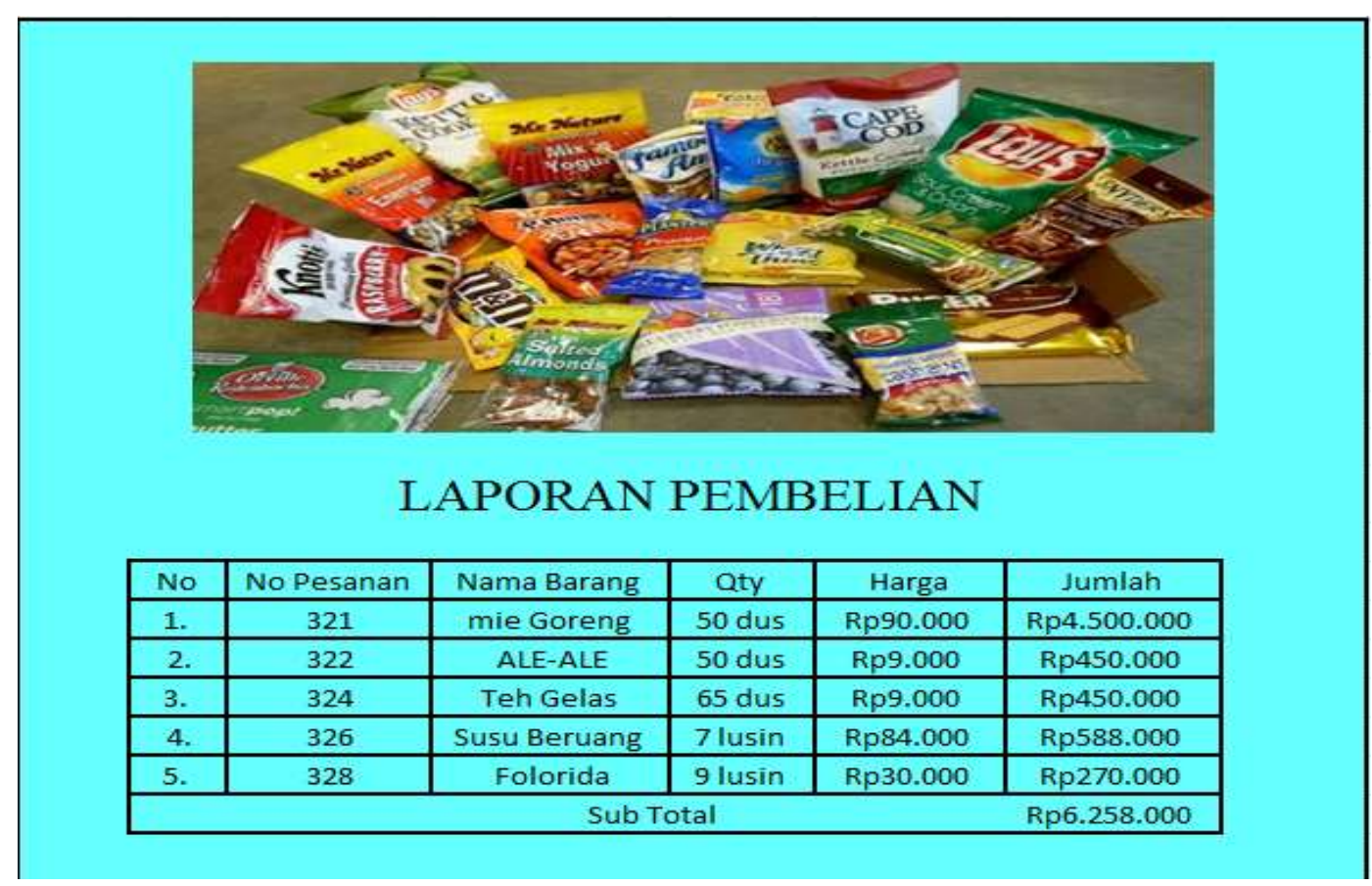

Gambar III.12

User Interface Hasil Laporan Pembelian 


\subsection{UserInterface Laporan Pembelian}

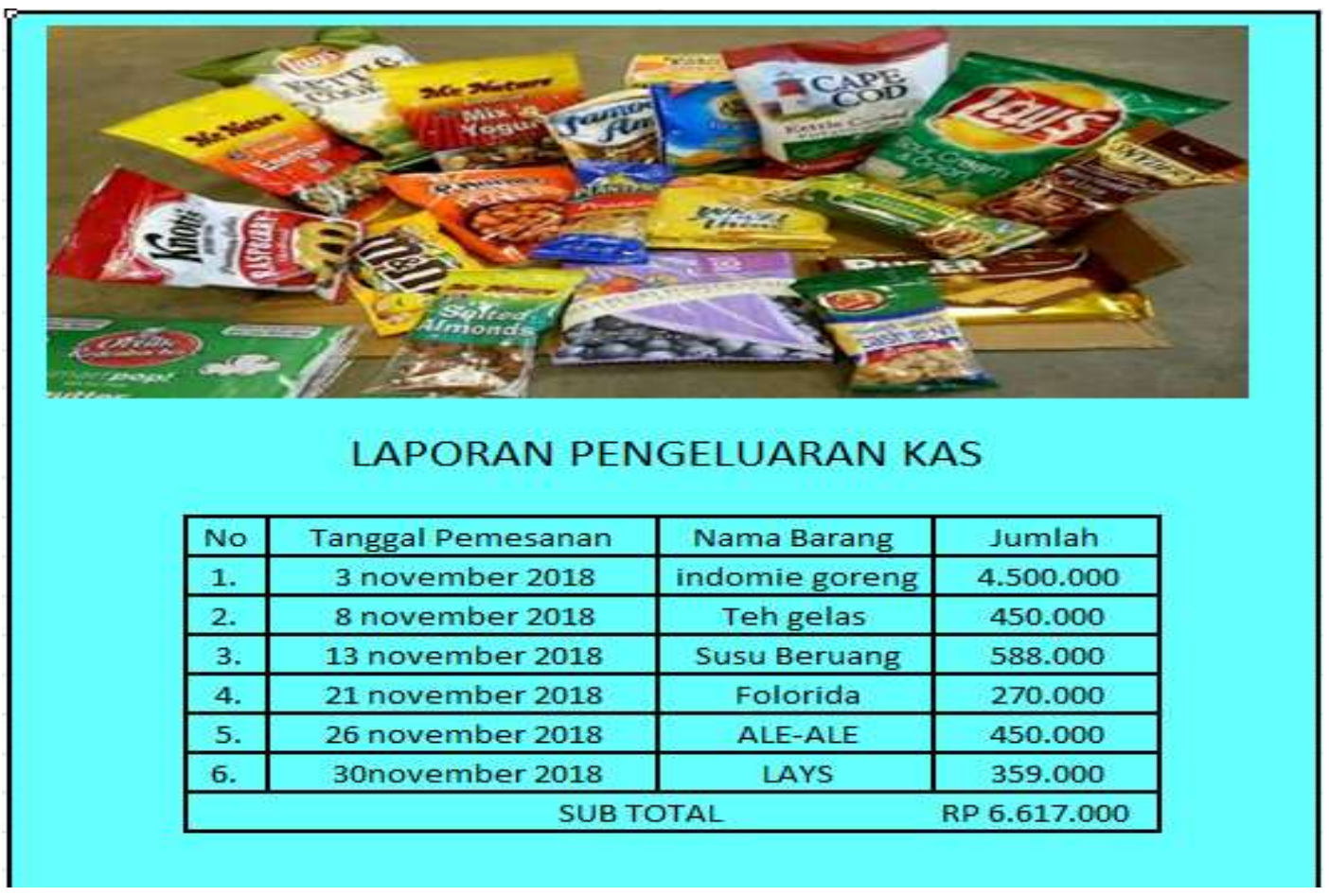

Gambar III.13

User Interface Laporan Pengeluaran Kas

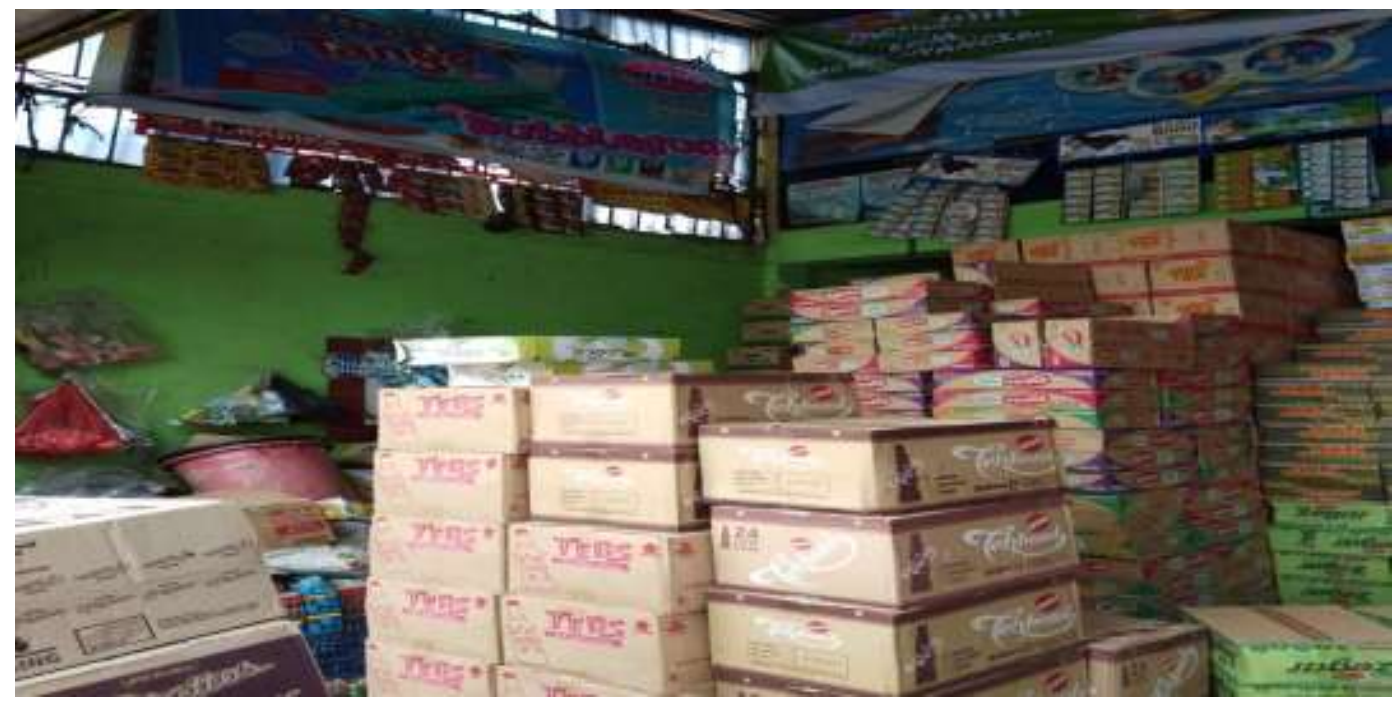

Gambar III.14

Toko Sabana II 


\section{Kesimpulan}

Permasalahan pokok sistem tersebut, penulis menarik beberapa kesimpulan antar lain :

1. Pengolahan data - data pembelian yang masih diproses dengan menggunakan Microsoft Excel menyebabkan sering terjadi kesalahan - kesalahan dalam proses pengolahan data transaksi penjualan seperti double input, kesalahan penginputan, kesalahan penomoran, maupun human error sehingga menyebabkan keterlambatan informasi.

2. Dengan dirancangnya sebuah aplikasi usaha dagang, permasalahan - permasalahan yang ada dalam sistem manual dapat teratasi seperti sistem tidak akan menerima data yang tidak lengkap, sistem dapat melakukan penomoran otomatis, serta meminimalisir kesalahan - kesalahan yang terjadi akibat manusia (human error), mengurangi jumlah penggunaan kertas, pembuatan laporan dapat dilakukan dengan mudah dan cepat karena data diolah dengan sistem.

3. Perancangan database virtual dalam sistem juga memberikan banyak manfaat antara lain sistem mampu menampung informasi dalam jumlah yang tak terhingga, informasi yang disajikan akan lebih teratur dan tersusun rapi sehingga memudahkan dalam proses pencarian informasi pada saat yang dibutuhkan.

Perkembangan teknologi terkomputerisasi tentu tidak akan efektif dan efisien jika tidak diimbangi dengan perkembangan sumber daya manusia. Sistem yang terkomputerisasipun tidak akan mampu mengatasi permasalahan yang ada jika karyawan atau sumber daya manusi tidak mampu mengikuti perkembangan sistem tersebut.

Oleh karena itu, untuk memperlancar dan menjaga kestabilan sistem dalam melakukan pengolahan data, penulis ingin memberikan saran yang diharapkan dapat bermanfaat bagi perusahaan, antara lain :

1. Kesiapan dan kedisiplinan karyawan terkait pelaksanaan sistem yang terkomputerisasi sehingga mengurangi tingkat kesalahan akibat manusia (human error) yang akan berpengaruh pada proses dan hasil transaksi.

2. Meningkatkan pengetahuan user terutama bagian usaha dagang dan bagian finance selaku pemakai program, baik masalah operasional maupun pengetahuan lain yang berhubungan dengan dunia komputer.

3. Perlu diadakan pengecekan dan pembaharuan program secara periodik untuk menjaga dan meningkatkan kualitas program guna membantu efektivitas dan efisiensi sistem informasi.

\section{Daftar Pustaka}

Anggraeni, E. Y., \& Irviani, R. (2017). Pengantar Sistem Informasi. (E. Risanto, Ed.). Yogyakarta: Penerbit Andi.
https://books.google.co.id/books?id=8VNLDw AAQBAJ\&pg=PA32\&dq=pengertian+hardwar e\&hl=id\&sa $=$ X\&ved $=0$ ahUKEwjI9cvuut $7 \mathrm{bAh}$ VIfSsKHZ0wDyUQ6AEILDAB\#v=onepage \& $\mathrm{q}=$ pengertian hardware $\& \mathrm{f}=$ false

Bakhri, S. (2015). Rancang Bangun Sistem Informasi Penjualan Sembako Menggunakan Metode Waterfall, 3(1), 70-82. https://doi.org/10.2311/EVO.V3I1.234

Hery. (2012). Pengantar Akuntansi 1. Jakarta: Fakultas Ekonomi Universitas Indonesia.

Muslihudin, M., \& Oktafianto. (2016). Analisis dan Perancangan Sistem Informasi Menggunakan Model Terstruktur dan UML. (A. Pramesta, Ed.). Yogyakarta: Penerbit Andi.

Puspitasari, D. (2015). Rancang Bangun Sistem Informasi Koperasi Simpan Pinjam Karyawan Berbasis Web. Seminar Nasional Ilmu Pengetahuan Dan Teknologi Komputer, XI(2), 186-INF.196.

Rahmawati, M. (2015). Peran Aplikasi Komputer Berbasis Akuntansi untuk Badan Usaha Dalam Persfektif Sistem Informasi, XIII(2), 172-183.

Ramanda, K., Rusman, A., \& Agustin, R. (2017). Rancang Bangun Sistem Informasi Service Center Pada PT . Catur Sukses Internasional Jakarta, 7(2), 1-5.

Rosa, A. S., \& Shalahuddin, M. (2016). Rekayasa Perangkat Lunak Terstruktur dan Berbasis (Puspitasari, 2015)Objek. Bandung: Informatika.

Syahputra, R., \& Amin, S. (2016). IOS Visual Programming. Yogyakarta: Mediakom.

\section{Biodata Penulis}

Mari Rahmawati. Menyelesaikan Pendidikan Strata-1 (S1) di STMIK KUWERA-HARVEST, Program Studi: Sistem Informasi, lulus pada tahun 2007 dengan gelar S.Kom. Ia melanjutkan studi Pascasarjana Magister Ilmu Komputer STMIK Nusa Mandiri, Program Studi: Sistem Informasi, Konsentrasi: e-Business, lulus pada tahun 2011 dan memperoleh gelar M.Kom. Penulis bergabung di Universitas Bina Sarana Informatika sejak tahun 2006-sekarang sebagai dosen tetap dan sudah memiliki Jabatan Fungsional Akademik: Lektor terhitung mulai tanggal 01 Agustus 2018.

E-mail: mari.mrw@bsi.ac. 
